\title{
EFFECT OF A BODY MODEL ON PERFORMANCE IN A VIRTUAL ENVIRONMENT SEARCH TASK
}

\section{CONTENTS}

Dismounted Soldiers and Simulation

Page

Body Representation

Simulator Sickness

Presence \& Immersive Tendencies

Body Model Experiment. $\ldots \ldots \ldots \ldots \ldots \ldots \ldots \ldots \ldots \ldots \ldots \ldots \ldots \ldots \ldots$

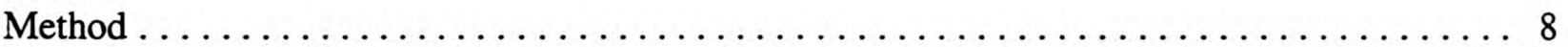

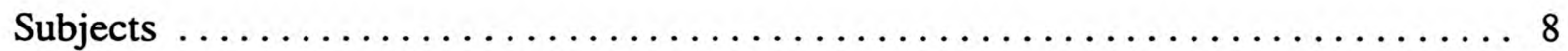

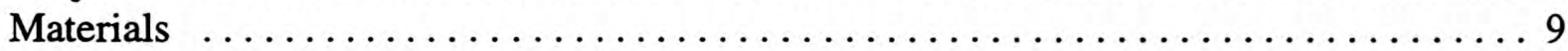

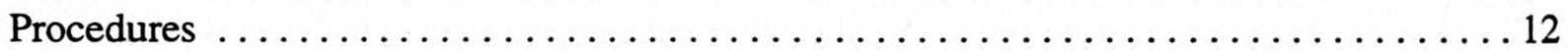

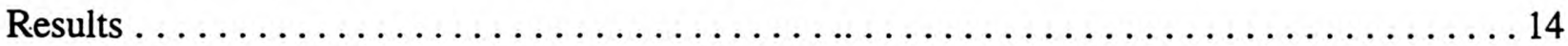

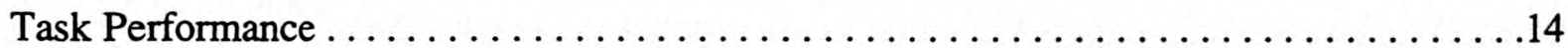

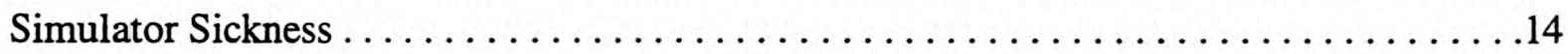

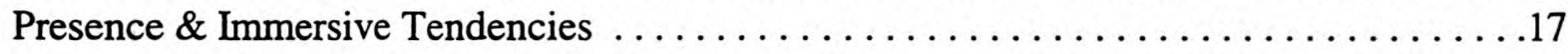

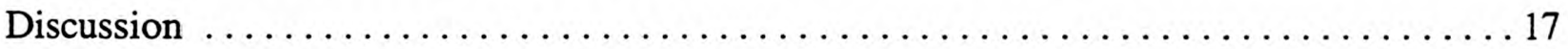

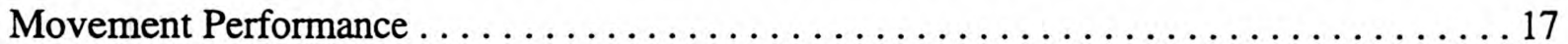

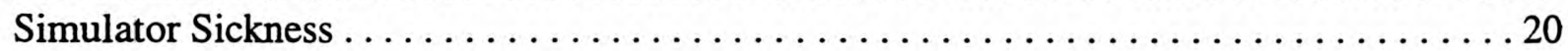

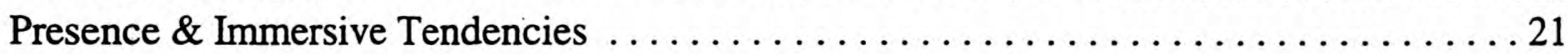

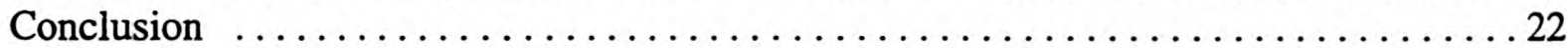

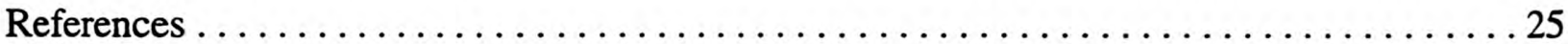

APPENDIX A. Research Participant Information Questionnaire $\ldots \ldots \ldots \ldots \ldots \ldots$ A-1 